\title{
PENGARUH N-ASETIL SISTEIN ORAL TERHADAP PENURUNAN HSCRP PADA PASIEN PENYAKIT GINJAL KRONIS STADIUM V YANG MENJALANI CONTINUOUS AMBULATORY PERITONEAL DIALYSIS (CAPD)
}

\section{THE EFFECT OF ORAL N-ACETYL CYSTEINE ON HSCRP LEVEL IN STAGE V CHRONIC KIDNEY DISEASE PATIENTS WITH CONTINUOUS AMBULATORY PERITONEAL DIALYSIS (CAPD)}

\author{
Evi Nurhayatun \\ Bagian Ilmu Penyakit Dalam, Fakultas Kedokteran, Universitas Sebelas Maret \\ Korespondensi: dr. Evi Nurhayatun. Email: evi.nurhayatun@gmail.com
}

\begin{abstract}
ABSTRAK
Inflamasi dan stres oksidatif adalah faktor resiko penyakit kardiovaskuler pada penderita penyakit ginjal kronis (PGK) stadium V. Pasien PGK yang menjalani CAPD mengalami peningkatan kadar HsCRP. N-Asetil Sistein (NAS) adalah antioksidan yang mengandung gugus tiol dengan efek antioksidan dan antiinflamasi. Penelitian ini bertujuan untuk membuktikan pengaruh NAS oral terhadap penurunan kadar HsCRP pada pasien PGK stadium $V$ yang menjalani CAPD. Penelitian ini merupakan penelitian eksperimen dengan Randomized Double Blind Control Trial, selama 8 minggu pada 30 pasien yang menjalani CAPD di RSUD Dr Moewardi yang telah memenuhi kriteria inklusi dan eksklusi. 30 pasien dibagi menjadi 2 kelompok (15 orang pada kelompok NAS, 15 orang pada kelompok plasebo). HsCRP diukur sebelum dan setelah perlakuan dengan NAS oral selama 8 minggu dan plasebo selama 8 minggu. Hasil didapatkan bahawa kadar HsCRP kelompok kontrol

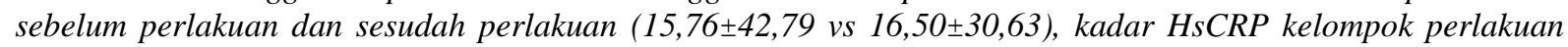
sebelum perlakuan dan sesudah perlakuan mengalami penurunan $(29,53 \pm 76,52$ vs 4,56 $\pm 12,85)$ secara signifikan dengan $p<0,05$. Pemberian NAS oral dapat menurunkan kadar HsCRP pada pasien PGK stadium $V$ yang menjalani CAPD.
\end{abstract}

Kata kunci : N-Asetil Sistein, CAPD, HsCRP

\begin{abstract}
Inflammation and oxidative stress are risk factors of cardiovascular diseases among chronic kidney disease patients. There is increasing of HsCRP level in stage V CKD patients wih CAPD. N-Acetyl Cysteine(NAC) is a compounds containing thiol with antioxidant and anti-inflammatory effects. This research obejectives was to examine the effect of oral NAC in the decline of HsCRP level in stage V CKD patients with CAPD. This is an experimental research with Randomized Double Blind Control Trial, involving 30 patients CKD with CAPD Dr Moewardi Hospital and complete inclusion and exclusion criteria, divided 15 patients as a control group (placebo) and 15 patients as a treatment group of oral NAC. Examination of data research variables have been performed before and after 8 weeks treatment. The results were the level of HsCRP in control group before treatment and after treatment $(15,76 \pm 42,79$ vs 16,50 $\pm 30,63)$. Level of HsCRP in treatment group before treatment and after treatment $(29,53 \pm 76,52 \mathrm{vs} 4,56 \pm 12,85)$ was decrease statistically significant with $p<0,05$. The N-Acetyl Cysteine orally can decreased the level of HsCRP in stage V CKD patients with CAPD.
\end{abstract}

Keywords : N-Acetyl Cysteine, CAPD, HsCRP

How To Cite: Nurhayatun, E. (2019). PENGARUH N-ASETIL SISTEIN ORAL TERHADAP PENURUNAN HSCRP PADA PASIEN PENYAKIT GINJAL KRONIS STADIUM V YANG MENJALANI CONTINUOUS AMBULATORY PERITONEAL DIALYSIS $\quad$ (CAPD). $\quad$ Biomedia, $11(1), \quad 1-4$. doi:https://doi.org/10.23917/biomedika.v11i1.3941

DOI: https://doi.org/10.23917/biomedika.v11i1.3941

\section{PENDAHULUAN}

Peningkatan stres oksidatif dan inflamasi kronis pada pasien penyakit ginjal kronis (PGK) yang menjalani dialisis telah banyak didokumentasikan (Oberg et al., 2004; Silvestein, 2009; Nanayakkara and Gailland, 2010; Fontanet et al., 2011). Kedua kondisi tersebut telah diketahui terkait dengan peningkatan morbiditas 
maupun mortalitas akibat penyakit jantung vaskuler pada pasien PGK yang menjalani dialisis melalui keterlibatannya dalam inisiasi dan progresi proses aterogenesis (Silvestein, 2009; Nanayakkara and Gailland, 2010; Fortes et al., 2007).

Mortalitas pada pasien dengan PGK mencapai $23 \%$ dengan penyebab penyakit jantung vaskuler (PJV) sekitar $40-45 \%$ dari seluruh penyebab kematian (Nanayakkara and Gailland, 2010; DeFilippi et al., 2003). Apabila penderita PGK menjalani dialisis, maka faktor terkait dialisis seperti bioinkompatibilitas dapat menyebabkan pelepasan sitokin proinflamasi dan disfungsi endotel yang mengarah ke percepatan aterosklerosis (Santoro and Mancini, 2002; Caballo, 2012).

Dialisis merupakan terapi yang sangat bermanfaat bagi penderita PGK. Di seluruh dunia terdapat 2.164.000 penderita PGK yang menjalani dialisis dan 235.000 diantaranya menjalani dialisis peritoneal (Fresinius Medical Care, 2012). Dialisis peritoneal khususnya Continuous Ambulatory Peritoneal Dialysis (CAPD) dengan berbagai kelebihannya merupakan salah satu pilihan (Burkart, 2004), tetapi CAPD dalam jangka panjang juga menyebabkan peningkatan resiko kardiovaskuler pada PGK. CAPD menginduksi inflamasi dan stres oksidatif seperti infeksi kronis dan faktor terkait cairan dialisat (Fortes et al., 2007).

Penanda inflamasi seperti Tumor Necrosis Factor - Alpha (TNF- $\alpha$ ) dan CRP meningkat seiring dengan penurunan fungsi ginjal menunjukkan bahwa PGK merupakan proses inflamasi kronis. Beberapa faktor dapat terlibat dalam memicu proses inflamasi termasuk stres oksidatif (Cachofeiro and David, 2008).

CRP yang merupakan acute phase reactant, diproduksi di liver yang diaktivasi oleh berbagai sitokin. Pada pasien-pasien yang di dialisis, adanya peningkatan kadar CRP menunjukkan adanya proses inflamasi. High sensitivity C-Reactive Protein (HsCRP) merupakan penanda inflamasi yang sudah diakui dan dapat menjadi prediktor kejadian PJV. HsCRP juga merupakan faktor yang kuat untuk memprediksi komplikasi dan kematian akibat penyakit kardiovaskuler (Honda, 2006).

Pada pasien PGK terjadi peningkatan HsCRP dan IL-6 sebanyak 25\% dari seluruh populasi dan adanya hubungan terbalik antara kadar HsCRP, IL-6 dengan fungsi ginjal (Panichi et al., 2000). $\mathrm{N}$-asetil sistein (NAS) merupakan suatu senyawa yang mengandung tiol dengan efek antioksidan dan antiinflamasi (Nascimento et al., 2010). Efek antioksidan NAS dapat terjadi secara langsung melalui interaksi dengan ROS elektrofilik maupun sebagai prekusor glutation (Dekhuijen, 2004), suatu antioksidan vital yang melindungi sel dari stres oksidatif yang diketahui menurun pada PGK (Santangelo, 2004).

Pengaruh suplementasi NAS oral terhadap penurunan kadar HsCRP pada pasien PGK yang menjalani CAPD belum pernah diteliti sebelumnya

\section{METODE}

Penelitian ini merupakan penelitian eksperimental dengan Randomized Double Blind Controlled Trial. Penelitian ini dilakukan di RS $\mathrm{X}$ Surakarta. Sampel penelitian diambil acak pada semua pasien PGK stadium $\mathrm{V}$ yang telah menjalani CAPD selama 3 bulan sampai 5 tahun di instalasi Ginjal Hipertensi RSUD Dr. Moewardi Surakarta, memenuhi kriteria inklusi dan eksklusi dan bersedia diambil darahnya untuk penelitian. Jumlah sampel 30 orang dengan pembagian 15 orang mendapatkan perlakuan dengan NAS oral dan 15 orang dengan plasebo selama 2 bulan. Analisis statistik menggunakan software.

\section{HASIL DAN PEMBAHASAN}

Hasil pengujian beda 2 mean kelompok kontrol dan perlakuan sebelum perlakuan adalah sebagai berikut (Tabel 1):

Tabel 1. Perbandingan Kadar HsCRP Kelompok Kontrol dan Perlakuan pada Sebelum Perlakuan

\begin{tabular}{ccccccc}
\hline \multirow{2}{*}{$\begin{array}{c}\text { Variabe } \\
\text { I }\end{array}$} & \multicolumn{2}{c}{ Perlakuan } & \multicolumn{2}{c}{ Kontrol } & \multicolumn{2}{c}{ Uji Beda 2 Mean } \\
\cline { 2 - 7 } & $\begin{array}{c}\text { Rata- } \\
\text { rata }\end{array}$ & $\begin{array}{c}\text { Std } \\
\text { Deviasi }\end{array}$ & $\begin{array}{c}\text { Rata } \\
\text {-rata }\end{array}$ & $\begin{array}{c}\text { Std } \\
\text { Deviasi }\end{array}$ & $\begin{array}{c}\text { Nilai } \\
\text { Statistik }\end{array}$ & $\begin{array}{c}\text { P } \\
\text { value }\end{array}$ \\
\hline HsCRP & 29,53 & 76,52 & 15,76 & 42,79 & Z=-0,394 & 0,713 \\
\hline
\end{tabular}

Keterangan: Signifikan pada derajat signifikansi 5 persen $(\mathrm{p}<0,05)$.

Berdasarkan hasil perhitungan perbedaan 2 mean kelompok kontrol dan perlakuan sebelum perlakuan tabel 1 di atas didapatkan kondisi awal kadar HsCRP (29,53 \pm 76,52 vs $15,76 \pm 42,76, p=0,713$ ) yang berarti tidak terjadi perbedaan atau kondisi yang sama.

Hasil pengujian beda 2 mean kelompok kontrol dan perlakuan pada sesudah perlakuan adalah sebagai berikut (tabel 2) :

Tabel 2. Perbandingan Kadar HsCRP Kelompok

Kontrol dan Perlakuan pada Sesudah Perlakuan

\begin{tabular}{ccccccc}
\hline \multirow{2}{*}{$\begin{array}{c}\text { Varia } \\
\text { bel }\end{array}$} & \multicolumn{2}{c}{ Perlakuan } & \multicolumn{2}{c}{ Kontrol } & \multicolumn{2}{c}{ Uji Beda 2 Mean } \\
\cline { 2 - 7 } & $\begin{array}{c}\text { Rata- } \\
\text { rata }\end{array}$ & $\begin{array}{c}\text { Std } \\
\text { Deviasi }\end{array}$ & $\begin{array}{c}\text { Rata- } \\
\text { rata }\end{array}$ & $\begin{array}{c}\text { Std } \\
\text { Deviasi }\end{array}$ & $\begin{array}{c}\text { Nilai } \\
\text { Statistik }\end{array}$ & P value \\
\hline HsCRP & 4,56 & 12,85 & 16,50 & 30,63 & Z=-2,054 & $0,041^{*}$ \\
\hline
\end{tabular}

Keterangan: * Signifikan pada derajat signifikansi 5 persen $(\mathrm{p}<0,05)$. 
Berdasarkan perhitungan beda 2 mean kelompok perlakuan dibandingkan kelompok kontrol sesudah perlakuan pemberian NAS pada tabel 2. didapatkan perbedaan variabel HsCRP $(4,56 \pm 12,85$ vs $16,50 \pm 30,63, p=0,041)$ dengan derajat signifikansi 5 persen $(\mathrm{p}<0,05)$. Dengan pemberian NAS terjadi penurunan kadar HsCRP pada kelompok perlakuan sementara pada kelompok kontrol tetap atau mengalami peningkatan.

\section{HsCRP \\ $\mathrm{p}<0,05$}

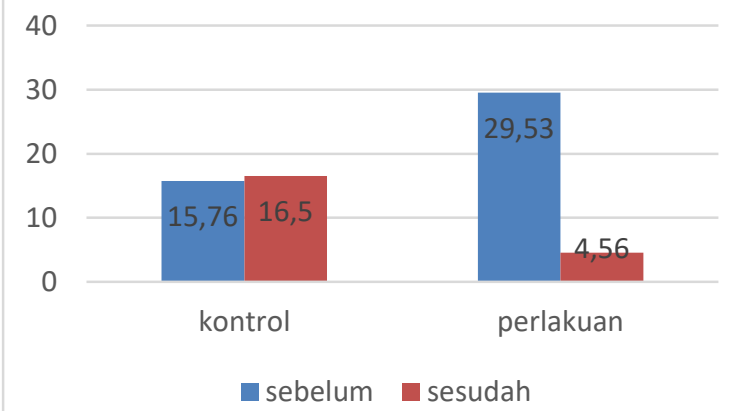

Gambar 1. Kadar HsCRP pada Kelompok Kontrol dan Kelompok Perlakuan Sebelum dan Sesudah Perlakuan

Hasil penelitian ini sesuai dengan kepustakaan bahwa tidak ada efek samping yang bermakna selama penggunaan NAS oral. Hal tersebut membuktikan keamanan NAS oral dalam penggunaan terapeutiknya. Banyak uji klinik NAS oral dengan indikasi khusus menggunakan dosis tinggi atau dalam pengobatan jangka panjang telah memperlihatkan bahwa obat NAS oral ditoleransi dengan baik. Namun kadang ditemukan keluhan gastro-intestinal (nausea, vomitus, dispepsia) dan jarang berupa urtikaria, anoreksia, vomitus, meteorisme (Shimizu, 2005; Borras, 2004; Aguiar-Souto, 2006). Hasil uji beda 2 mean dengan uji t untuk HsCRP sebelum perlakuan menunjukkan tidak signifikan pada derajat signifikansi 5 persen $(p>0,05)$, berarti rata-rata variabel utama HsCRP pada kelompok kontrol dan kelompok perlakuan itu tidak bervariasi secara meyakinkan atau sama untuk 2 kelompok penelitian.

Hasil analisis Willcoxon untuk uji beda 2 mean sampel berhubungan menunjukkan bahwa uji terhadap variabel HsCRP pada kelompok kontrol, keduanya tidak signifikan pada derajat signifikansi 5 persen, dapat disimpulkan bahwa kadar HsCRP pada kelompok kontrol tidak mengalami perubahan setelah mendapatkan plasebo selama delapan minggu. Bahkan terjadi peningkatan rata-rata kadar HsCRP. Hasil ini sesuai dengan kepustakaan yang menyatakan bahwa penanda inflamasi seperti IL-6 dan HsCRP meningkat seiring dengan penurunan fungsi ginjal pada PGK (Cochofeiro and David, 2008). Hasil analisis beda 2 mean sampel berpasangan dengan uji Willcoxon menunjukkan bahwa uji terhadap variabel kadar HsCRP pada kelompok perlakuan keduanya signifikan pada derajat signifikansi 1 persen $(\mathrm{p}<0,01)$, sehingga dapat disimpulkan bahwa kadar HsCRP pada kelompok perlakuan itu benar-benar mengalami perubahan penurunan yang meyakinkan. Hal itu dapat diartikan bahwa dengan pemberian NAS oral berpengaruh secara meyakinkan terhadap penurunan kadar HsCRP.

Hasil penelitian ini sejalan dengan hasil penelitian Nascimento et al., dimana pemberian NAS oral dapat menurunkan kadar sitokin inflamasi pada pasien yang menjalani peritoneal dialisis (Nascimento et al., 2010).

\section{SIMPULAN}

Pemberian NAS oral dapat menurunkan kadar HsCRP pada pasien PGK stadium V yang menjalani CAPD.

\section{DAFTAR PUSTAKA}

Aguiar-Souto, P. Valero-González S, Domínguez JF. 2006. N-Acetylcysteine and Contrast Induced Nephropathy. N Engl J Med. 5 ;355(14) : Pp 1497-8

Borrás C, Esteve JM, Viña JR, Sastre J, Viña J, Pallardó FV. 2004. Glutathione regulates telomerase activity in 3T3 fibroblasts. J Biol Chem. 279 (33). Pp: 34332-5

Burkart J. 2004. Metabolic consequences of peritoneal dialysis. Semin Dial. 17(6). Pp: 498-504.

Caballo C. 2012. NFkB in the development of endothelial activation and damage in uremia: an in vitro approach. PLOS ONE 7(8). Pp: 4337 
Cachofeiro V dan David D. 2008. Oxidative Stress and Inflammation, a Link Between Chronic Kidney Disease and Cardiovascular Disease. Kidney Int. 74. Pp: 54-9.

DeFilippi C, Wasserman S, Rosanio S, Tiblier E, Sperger H, Tocchi M, et al. 2003. Cardiac troponin T and $\mathrm{C}$-reactive protein for predicting prognosis, coronary atherosclerosis and cardiomyopathy ini patients undergoing long-term hemodialysis. Journal of American Medical Association. 290. Pp: 353-9.

Dekhuijzen PNR. 2004. Antioxidant Properties of $N$-Acetylcysteine: Their Relevance in Relation to Chronic Obstructive Pulmonary Disease. Eur Respir J. 23. Pp: 629-36.

Fresinius Medical Care. 2012. ESRD patients in 2011 : a global perspective. The Annual Fresenius Medical Care Market Survey, Pp: 4-10

Fontanet PR, Gómez L, Lartundo Q, Unzueta G, Fraile GM, Rodríguez T, et al. 2011. Markers of Inflammation Before and During Peritoneal Dialysis. Advances In Peritoneal Dialysis. Pp: 27.

Fortes PC, Versari PH, Stinghen AEM, Pecoits-Filto R. 2007. Controlling Inflammation in Peritoneal Dialysis: the Role of PD-related Factors as Potential Intervention Targets. Periton Dialysis Int. 27. Pp: 576-9.

Honda H. 2006. Serum albumin, C-Reactive Protein, Interleukin 6 and fetuin A as predictors of malnutrition, cardiovascular disease and mortality in patients with ESRD. Am J Kidney Dis. 47(1). Pp: 139-4811

Nanayakkara PWB dan Gaillard CAJM. 2010. Vascular Disease and Chronic Renal Failure: New Insights. Neth J Med. 68(1). Pp: 68

Nascimento MM, Suliman ME, Silva M, Chinaglia T, Marchioro J, Hayashi SY, et al. 2010. Effect of Oral N-Acetylcysteine Treatment on Plasma Inflammatory and Oxidative Stress Markers in Peritoneal Dialysis Patients: A Placebo-Controlled Study. Periton Dialysis Int. 30. Pp: 336-42.

Oberg BP, McMenamin E, Lucas FL, McMonagle E, Morrow J, Ikizler TA, et al. 2004. Increased Prevalence of Oxidant Stress and Inflammation in Patients with Moderate to Severe Chronic Kidney Disease. Kidney Int. 65. Pp: 1009-16.

Panichi V, Migliori M, De Pietro S, Taccola D, Bianchi AM, Norpoth M, et al. 2000. C reactive protein as marker of chronic inflammation in uremic patients. Blood Purificat. 21. Pp: 29-36

Santangelo F, Witko-Sarsat V, Drüeke T, Descamps-Latscha B. 2004. Restoring Glutathione as a Therapeutic Strategy in Chronic Kidney Disease. Nephrol Dial Transplant, 19. Pp: 1951-5.

Santoro A dan Mancini E. 2002. Cardiac Effects of Chronic Inflammation in Dialysis Patients. Nephrol Dial Transplant. 17(8). Pp: 10-15.

Shimizu MH, Coimbra TM, de Araujo M, Menezes LF, Seguro AC. 2005. N-acetylcysteine Attenuates the Progression of Chronic Renal Failure. Kidney Int. 68. Pp: 2208-17.

Silverstein DM. 2009. Inflammation in Chronic Kidney Disease: Role in The Progression of Renal and Cardiovascular Disease. Pediatr Nephrol. 24. Pp:1445-52. 